\title{
Theoretical model for interdisciplinary analysis of human activities: Meliponiculture as an activity that promotes sustainability
}

\author{
Celso Barbiéri \\ Tiago Mauricio Francoy
}

${ }^{1}$ Environmental Manager, Master and Doctoral Student in Sustainability at USP School of Arts, Sciences and Humanities

São Paulo/SP - Brasil

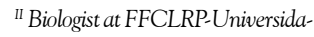
de de São Paulo, PhD in Genetics at Ribeirão Preto Medical School (2007) and Associate Professor at EACH-USP

São Paulo/SP - Brasil

\begin{abstract}
Meliponiculture, which is the rational keeping of stingless bees, has been practiced for centuries by pre-colonial populations and has been gaining adepts in recent years. In addition to being an alternative for the conservation of these pollinators, it is an activity that promotes sustainability. From a theoretical point of view, disciplinary approaches are insufficient to understand meliponiculture, due to the multiplicity of Domains and aspects that compose it. Thus, this manuscript proposes a theoretical model to analyze meliponiculture in an interdisciplinary way, dealing with the environmental, cultural, social and economic Domains. Such activity should be encouraged through participatory and interdisciplinary public policies, integrating the various factors involved, such as honey farmers (meliponists), scientists, governments, companies and non-governmental organizations. Public policy approaches to meliponiculture as an economic activity must respect the conservation needs of the stingless bee species, and whenever possible, the social and cultural values attributed to the activity.
\end{abstract}

Keywords: Stingless Bees, Interdisciplinarity, Conservation Biology

São Paulo. Vol. 23, 2020

Original Article

DOI: http://dx.doi.org/10.1590/1809-4422asoc20190020r2vu2020L4AO 


\section{Introduction}

Pollinating organisms play a fundamental role in the maintenance of global biodiversity, officially recognized after the approval of the Convention on Biological Diversity, of which Brazil is a signatory. The convention was part of the United Nations Conference on the Environment (Eco-92) held in Rio de Janeiro, in 1992. In Brazil, the text of the Convention on Biological Diversity was transformed into an official decree, in 1994 (BRASIL, 1994).

Subsequently, in 1998, after a meeting involving pollination and pollinators specialists from around the world, the document Declaration on Pollinators was published, which was presented to the Convention on Biological Diversity for the implementation of an International Pollinator Initiative (IPI). In the same year, the Brazilian Pollinator Initiative was also created, as a way to reinforce the importance of these organisms and provide better management of knowledge building and spreading (IMPERATRIZFONSECA et al. 2007).

About $75 \%$ of the more than 240,000 species of angiosperms in the world depend, for their reproduction, on pollinating agents, such as wind, water, animals such as some birds, bats, insects, and others. Among them, bees are the most important pollinators, since they are responsible for the pollination of approximately $73 \%$ of the species cultivated in the world (FREITAS, 2004). According to Gallai et al. (2009), the total economic value of world pollination corresponded to the equivalent of $9.5 \%$ of the value generated by agricultural production used for human consumption in 2005. The global economic value of pollination was calculated by the IPBES (Pollinator, Pollination and Food Production Evaluation Report) of the Intergovernmental Science-Policy Platform on Biodiversity and Ecosystem Services, estimated at somewhere between US \$235 billion and US \$ 577 billion (POTTS et al. in IPBES 2016). In this sense, bees have enormous ecological and economic importance, both for the conservation of the majority of native plant species, as for their use in pollination programs applied to crops (MESQUITA, 2009), so that they need special attention in the field of conservation (SILVEIRA et al., 2006).

Among the various groups of bees, we find the Meliponini tribe, whose species are popularly known as indigenous stingless bees, due to the fact that they have an atrophied vestigial sting. They do not, however, lose the ability to defend their nests, possessing various defensive strategies for this purpose, from wrapping themselves in hair, nibbling on the aggressor's skin, entering body cavities such as mouth, ears, and nostrils, or depositing plant resins on enemies. The less defensive species, on the other hand, protect their nests building them in places of difficult access, such as in anthills or close to nests of other more defensive bee species, gaining protection (OLIVEIRA et al., 2013).

The rational keeping of these bees is called meliponiculture, a term coined in 1953 by researcher Paulo Nogueira Neto, one of the precursors of the stingless bees studies in Brazil. Venturieri et al. (2007) restricted the term a little more, defining meliponiculture as the keeping of stingless bees associated with the species that produce and store more honey. However, regardless of the definition, this is an ancient practice from before the colonization of the Americas by the Europeans. The products of stingless bees and, in 
some cases, their creation were part of the socio-cultural customs, including food, medicinal, ritualistic, and commercial aspects of many Amerindian societies (PALAZUELOSBALÍVAM, 2008).

They are also important for religious, cultural, and economic aspects. Because they store considerable amounts of honey and pollen in their nests, and because they produce a large quantity of cerumen, some species of stingless bees represent an essential source or supplement of income for many families (CORTOPASSI-LAURINO et al., 2006).

\section{The decline of bee populations}

Reports indicate that stingless bees are suffering a process of population decline, caused mainly by the deforestation of native forests, the preferred nesting environment for the vast majority of these species (LOPES et al., 2005). Kerr et al. (2010) also point to deforestation, burning, and the expansion of urban areas in regions that used to be native forests as causing the reduction of pollinator biodiversity, as they impact their food resources and nesting sites.

Currently, the indiscriminate use of pesticides is one of the leading causes of the decline in bee populations. There is evidence of lethal and sublethal effects, such as malformation of the larvae, reduced life expectancy, and wing asymmetry of Scaptotrigona aff depilis (ROSA et al., 2016). This species is indicated as a good indicator of pesticide contamination (ROSA et al., 2015). It is worth mentioning that not only pesticides have been presenting adverse effects on bee populations, but also fertilizers, which impact both the survival and the flight behavior of Friesella schrottkyi (RODRIGUES et al. 2017), and can also have the same effect on other species. Thus, meliponiculture, as a colony maintenance tool, has excellent potential for the conservation of native stingless bees, since it stimulates the maintenance of nests and the multiplication of swarms.

\section{Sustainability}

Several authors have already discussed the concepts of sustainability and sustainable development, such as the classic definition of the Brundtland report named Our Common Future. However, although there are hegemonic approaches to the definition of sustainability, we understand that it is more a mosaic of concepts, which relates its multiple aspects, than a simple and unique concept.

Martens (2006) identified three fundamental characteristics of sustainability. The first indicates that sustainability is an intergenerational phenomenon. It means that for something to be considered sustainable, it must last longer than the time of a generation. This duration is a necessary characteristic because, by providing comfort and prosperity for humanity, even with certain conservation of natural resources, it is not a sustainable situation if it does not last over time. The second common characteristic is the level of scale. Sustainability must be practiced at several levels, ranging from global to regional and local. What can be seen as sustainable at the national level is not necessarily sustainable 
at the international level. This geographic incompatibility derives from different interests of nations, so that it can result in negative consequences for a given country or region. The third common characteristic is that of multiple Domains. Sustainable development consists of at least three domains: economic, ecological, and socio-cultural.

According to Kates (2011), the science of sustainability has the challenge of conducting dialogues between different areas of knowledge, breaking geographical, social and methodological barriers, in order to, finally, guide public and business policies at regional, national and international scales.

Farley (2010) presents a metaphor, in which he compares the problems related to the loss of biodiversity and its conservation with the composed eyes of a dragonfly (or a bee): each compound eye captures a part, or aspect, of a larger image. This metaphor can be expanded to the discussion on sustainability as a whole, and applied to the understanding of meliponiculture activity, which is, according to Venturieri et al. (2003), ecologically sustainable, economically viable, and socially fair. Besides, those three characteristics contemplate the classic tripod of sustainability proposed by John Elkington, in 1994. However, it is important to point out that the widely criticized (and called for recall by the author, in 2018, in order to rethink the discussion on corporate sustainability) tripod of sustainability is insufficient to analyze the characteristics and benefits of meliponiculture to the present and future times.

\section{OBJECTIVES}

Given this multiplicity of Domains, we propose a theoretical model to facilitate the understanding of activities through the prism of sustainability, with meliponiculture being both the example and the object of analysis. Furthermore, before starting the analysis itself, it should be noted that the proposed format and the identified Domains are not intended to be a definitive way of analyzing meliponiculture or any activity that uses natural resources, but rather to provide a tool to structure the analysis and expand its understanding. Thus, we seek to contribute both with the knowledge about the activity of meliponiculture, as well as with the research methodologies on sustainability applied to economic activities that use natural resources and ecosystem services.

\section{METHODOLOGY}

In a reinterpretation of the compound eyes approach, for a better understanding of the meliponiculture activity, analysis at different levels must be made, as it involves multiple Domains, which can be discussed separately or together, in broad or more restricted contexts.

The following analysis was made based on the available literature on meliponiculture, and exploratory research carried out by the authors in events focused on the activity between 2014 and 2019, including participation in meliponiculture seminars and meliponists meetings in Southeastern Brazil. Information was collected both from 
discussions at events on meliponiculture and meliponists meetings, as well as from open interviews with meliponists. Observations were also included, made during interviews for quantitative research on meliponiculture, conducted by the same authors of this manuscript. Spontaneous reports of interviewed meliponists are also part of the content presented for the demonstration of the theoretical model.

\section{Meliponiculture and Sustainability}

Although meliponiculture practice is a simple activity, the factors involved are complex, with a myriad of interactions between the human hand and the environment. For the present work, the main Domains identified are Environmental, Social, Cultural, and Economical.

\section{Economic Domain}

Meliponiculture has been going through a recent process of popularization, with several initiatives using this activity as a means of production. Here we identify the main economic aspects of meliponiculture (Figure 1).

\section{Figure 1 - Economical Domain of Meliponiculture}

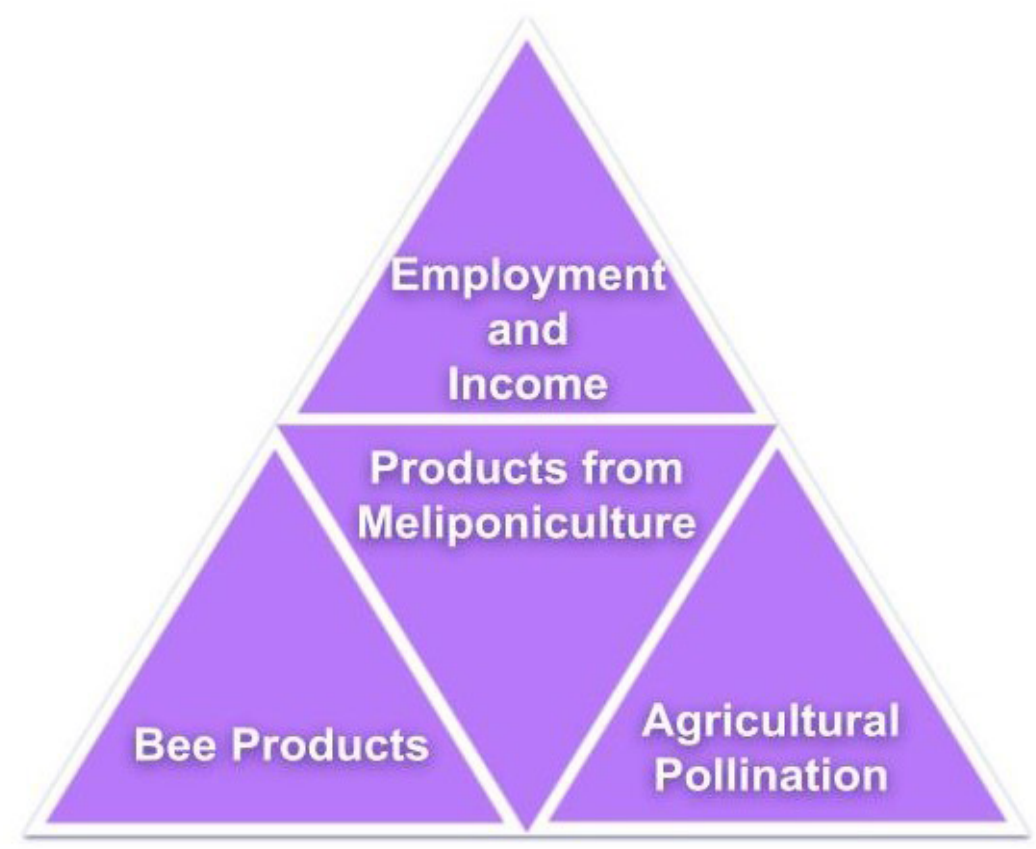

Source: Barbiéri and Francoy (2020) 
Bee products - The direct products of the bees correspond to natural resources that are collected or produced by them, and that can be exploited commercially. Among these resources, there are honey, pollen, propolis, cerumen (a mixture of wax and propolis made by stingless bees), in addition to the bee colonies themselves. In the last decade, the search for new honey flavors, mainly on the part of the haute cuisine sector, has stimulated the activity of meliponiculture, generating an interest increase in relation to the kinds of honey produced by native bees, due to the disclosure of these products by internationally renowned chefs (VILLAS-BÔAS, 2017). The use of honey is extensive and can be consumed fresh or as part of sweet and savory recipes. Due to the diversity of bee species and floral origins, these honeys are often compared to wines, given their unique sensory characteristics. The pollen of stingless bees has also been gaining space in haute cuisine, being used mainly as a seasoning, due to its intense flavors. As for cerumen, some meliponists have been testing and developing new products, such as aromatic candles (aroma from the propolis contained in the product), handmade cosmetics as lip balms (VILLAS-BÔAS, 2018), and even alternatives to the use of paraffin on surfboards. Propolis, on the other hand, shows enormous potential in the pharmacological sector, having already shown antibiotic effects (MAIA-FILHO, 2008), besides the inhibition of certain types of cancer in animal models (ARAÚJO, 2010). The interest in bee colonies is mainly due to the expansion and popularization of the activity in Brazil, which consequently increases the demand for colonies. Thus, the production of colonies from the induced rational multiplication may also be explored as a form of economic gain.

Products for meliponiculture - In recent years, virtual stores have appeared, dedicated only to the commercialization of products for the meliponiculture activity. Those products are as follows: attractive scents for swarms, rational hives, tools, trap nests, nests, and other miscellaneous items, which are widely marketed by meliponists and for meliponists. The sales of these and related items is also an alternative option of economic gain within the field of meliponiculture.

Agricultural pollination - The pollination carried out by stingless bees, directed to specific cultures, as is already done by Australian stingless beekeepers (HALCROFT, 2013), is an activity with enormous potential that is not yet well explored in Brazil. Only in recent years, it has been treated with more attention by initiatives, to stimulate targeted pollination, such as the ApiAgri initiative, which developed an application aimed at connecting farmers interested in renting bee colonies to pollinate their crops and beekeepers (honey bee and stingless beekeepers) who can supply these colonies.

Employment and income - According to Venturieri et al. (2003), the rational keeping of stingless bees is an essential activity for income and employment generation, helping to increase the life quality of the honey producer. Several initiatives have contributed to the generation of employment and income through meliponiculture, such as the project developed by the Instituto Socioambiental (ISA) in the Xingu Indigenous Land (TIX), with indigenous meliponists, who sell the excess honey produced to restaurants in São Paulo ( VILLAS-BÔAS, 2017). The Tupyguá cooperative in Espírito Santo is also a successful case of community-based meliponiculture that adds income to producers. In 
recent years, some companies have started to sell stingless bee honey. These companies have the peculiarity of valuing the regionalism of the produced honey. The main examples of this regard are the companies Mbee, which sells different kinds of honey from small producers all over Brazil, stimulating local production chains, and Beeliving, which sells honey from the Atlantic Forest. In January, 2019, the Peabiru Institute started to market the first honey from stingless native bees with the stamps of the Ministries of Agriculture, of Livestock and Supply, and of the Environment.

\section{Cultural Domain}

The same pyramid model can be used to represent the cultural Domain (Figure 2), which, for the case of meliponiculture, represents a link between the traditional and the innovative; between basic education and scientific development.

Figure 2 - Cultural Domain of Meliponiculture

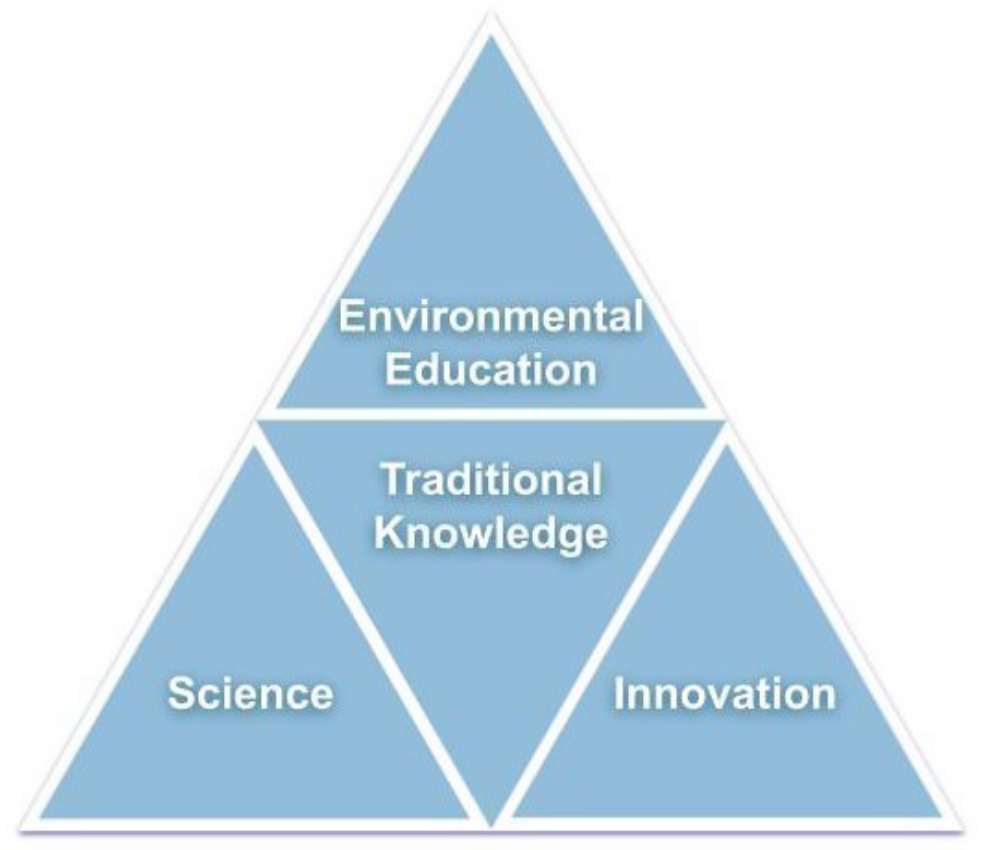

Source: Barbiéri and Francoy (2020)

Traditional knowledge - Traditional knowledge is the foundation pillar of meliponiculture, since it started with the indigenous populations of the Americas and is still maintained in some regions of Brazil and the world (CARVALHO et al., 2014). These populations developed a very close relationship with meliponiculture, with bees as part of their religious rites (PALAZUELOS-BALÍVAM, 2008). Some populations, such as the Kayapós, developed their methods for classifying bee species, anatomy and structure 
of the nests, in a very similar way to that of contemporary science, as shown by the study by Posey and Camargo (1987). Some of these traditional communities have an incomegenerating activity in meliponiculture, mainly due to socio-environmental projects that strengthen this community-based production chain in several regions of Brazil (VILLASBÔAS, 2018).

Innovation - On the other hand, meliponiculture is an activity full of innovations and space for new ideas. Meliponists develop new techniques and tools to deal with species diversity, behavior, and overcome particular difficulties in their management. Although most of this innovation occurs empirically, novelties are frequently presented on social networks and events focused on meliponiculture, being often left aside by the academic environment.

Science - There is much space for scientific development related to meliponiculture, stimulating this interface between the innovations coming from the meliponists and the members of the scientific community. If the two sides worked with a more joint approach, it would allow the absorbing, testing, and validating of the knowledge and innovation produced by meliponists, as well as providing new knowledge for more efficient management, helping to continue the development of the activity sustainably. Much can still be done concerning the development of basic research on the field of biology and management of stingless bees and applied research for the sustainable use of bees and their products.

Environmental education - Some initiatives have been using meliponiculture as an educational tool for teaching the themes of the importance of bees and pollination. Some of these initiatives are the NGO Bee or not to be, the Meliponicultura.org initiative, the project SOS Abelhas sem Ferrão in São Paulo and the project Enxameia, which operates in Mato Grosso do Sul. According to Barbiéri (2018), one of the main objectives of the stingless beekeeping in the state of São Paulo is environmental education. Since 2017, meliponiculture has become a scouting specialty, based on joint action between the SOS Abelhas sem Ferrão project and the Brownsea First Scout Group. The entry of meliponiculture in the list of scouting specialties represents the initial contact of thousands of children and adolescents with the theme of bee conservation and the importance of pollination, in addition to encouraging these young people to know the subject in greater depth to obtain the specialty badge. Educational materials aimed at environmental education with the theme of bees have also been successfully used. Some examples are the book "The invisible link" that, through a children's story, brings children closer to stingless bees, and the Bee or not to Be NGO's Environmental Education Activities Notebook (PERUCHI and GONÇALVES 2015).

\section{Social Domain}

In the pyramid that makes up the Social Domain of meliponiculture (Figure 3), some intangible benefits generated by the activity are highlighted. 
Figure 3 - Social Domain of Meliponiculture

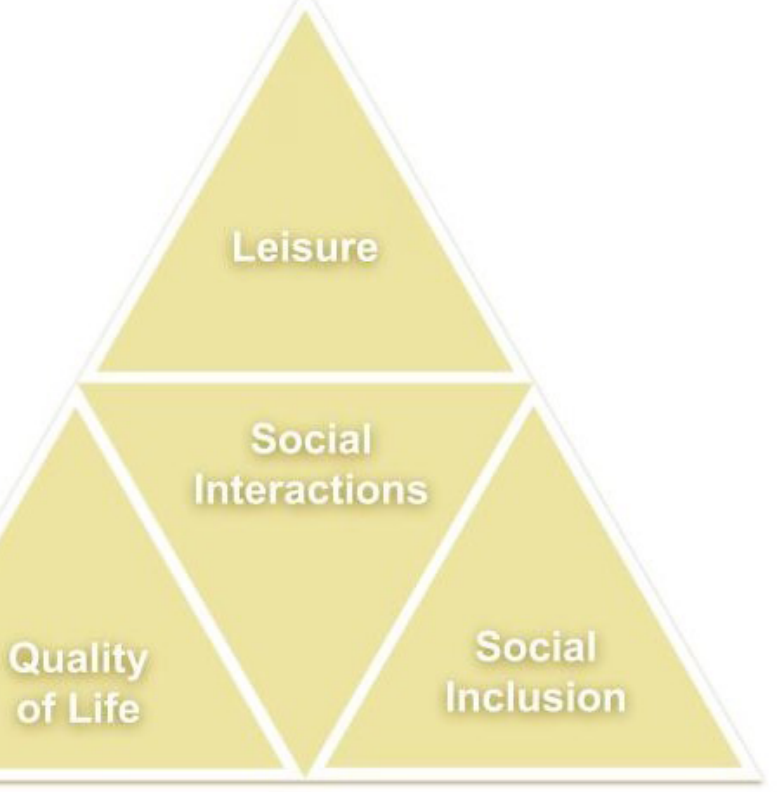

Source: Barbiéri and Francoy (2020)

Leisure - Due to the low risk of accidents when compared to traditional beekeeping, the possibility of harvesting honey and performing a series of practices and management are described as fun and relaxing by many meliponists. Thus, the practice of meliponiculture as a recreational activity is an essential factor in the popularization of the activity, leading beekeepers to come into contact with a series of fundamental values of sustainability. According to Villas-Bôas (2018), recreational meliponiculture is an important step for conservationist meliponiculture, if well oriented, in addition to promoting the conservation of several species.

Social interactions - The generation of interactions and social relationships between beekeepers is one of the benefits generated by the activity. Meliponists have been forming very active communities, with local and regional meetings gathering hundreds of people, in addition to the extensive use of social networks for discussions involving the subject. There are now social media groups with thousands of active members. In this way, meliponiculture can, also, create bonds of friendship between beekeepers. According to Barbiéri (2018), online social networks are the primary vehicle for learning about the topic in the state of São Paulo. The use of social networks and the participation of beekeepers in seminars and meetings are significant for knowledge exchange and the popularization of the activity. It is also important to mention that since its foundation, the NGO Bee or not to be has promoted several meliponiculture events in Southeast Brazil, mainly in São Paulo, providing both social interactions between meliponists and 
the transmission of management techniques.

Social inclusion - Due to the low initial cost, and because it is an elementary activity at the starting point (but that requires much knowledge at a more advanced level), meliponiculture can be used as a tool for social inclusion and can be promoted among communities in need, working together with familiar agricultural activities. For meliponiculture to expand in terms of social inclusion, public policies that unite social inclusion, regional development, and conservation must be implemented. A notable example of social inclusion through meliponiculture is the Hebora project, which trains low-income countryside women, many of them considered as "settled peasants", aiming at social inclusion and economic independence. The project assists countryside women from the training and assembly of the meliponary to the honey and bee's products marketing. Additionally, actions to popularize the activity should be encouraged, such as the provision of courses and workshops for the population in general, but mainly for needy communities.

Quality of life - A benefit frequently reported by honey farmers is the improvement in quality of life, generally attributed to the adoption of sustainable practices such as independent food production, greater concern with the origin and destination of the consumed products, and the motivation generated by making some management on bees. A lasting example of a project combining meliponiculture and an increase in the quality of life is the Bees for the Best Age, an extension course held annually since 2003 at USP in Ribeirão Preto. The project aims to teach retirees a new activity based on practical and theoretical activities, encouraging the elderly to remain intellectually active after retirement (FREITAS, 2003). There are frequent reports of meliponists who practice meliponiculture not only as a form of leisure but also as a therapeutic resource against depression and anxiety, a topic that deserves attention and dedicated studies in the field of psychology.

\section{Environmental Domain}

Finally, we will address the benefits generated by meliponiculture in the Environmental Domain (Figure 4), essential for any discussion of meliponiculture and sustainability. The aspects related to this Domain are: Environmental Awareness, Biological Conservation, Environmental Recovery, and Maintenance of Ecosystem Services. 
Figure 4 - Environmental Domain of Meliponiculture

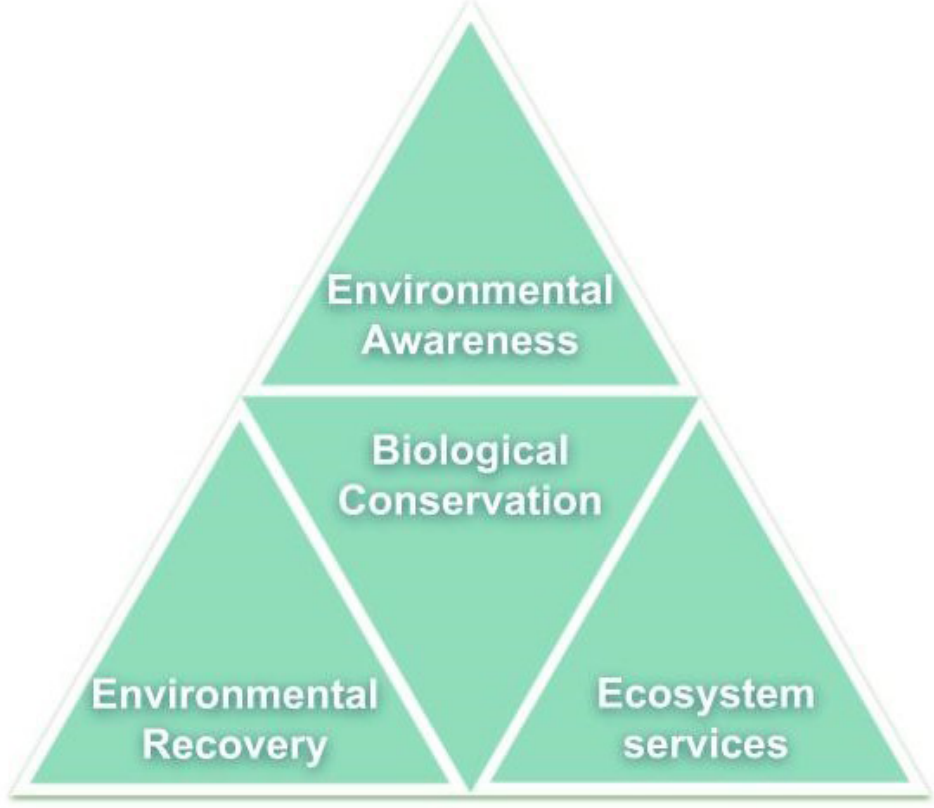

Source: Barbiéri and Francoy (2020)

Maintenance of ecosystem services - One of the benefits generated by meliponiculture is the maintenance of ecosystem services, since, in the keeping of stingless bees, meliponists maintain a large number of pollinating agents responsible for pollination service. From this perspective, stimuli to the development of rational meliponiculture are essential for the preservation of both stingless bees and plant populations dependent on their pollination. According to Kerr et al. (1996), stingless bees may be responsible for pollinating up to $30 \%$ of the plant species in the Caatinga and Pantanal biomes, reaching up to $90 \%$ of the pollination of some remaining fragments of the Atlantic Forest.

Environmental recovery - A peculiar aspect of meliponiculture is the promotion of environmental recovery. A widespread practice among stingless beekeepers is to cultivate plants that provide resources for stingless bees, such as pollen, nectar, and resins. Due to the need to provide resources for bees, the meliponists, in addition to promoting plantings of native plants, exchange seedlings and plant seeds that supply these resources, improving environmental quality, even in urban environments. Although these environments are, in general, quite degraded, they represent crucial refuges for pollinator populations (HALL et al., 2017). When dealing with commercial meliponiculture, we can consider environmental recovery as a positive externality of the meliponiculture production chain.

Environmental awareness - Understanding the importance of bees and pollination to the environment, such as the maintenance and restoration of flora, is almost a manda- 
tory consequence of meliponiculture. Barbiéri (2018) and Jaffé et al. (2015) pointed out that environmental problems such as monocultures, deforestation, use of pesticides, and the spraying of insecticides in urban areas for the control of disease vector mosquitoes are widely perceived and considered dangerous by meliponists. Understanding ecosystem services and the environmental problems involved in the human-environment relationship is an essential part of environmental awareness, which is essential for the promotion of sustainable practices.

Biological conservation - The promotion of biological conservation characterizes the rational keeping of stingless bees, both for the bees themselves and for the plants dependent on their pollination. Given the advance of deforestation in Brazil, and the dependence of stingless bees on nesting sites, rational meliponaries are relevant maintainers of this biodiversity (COSTA et al., 2014). Both recreational and professional meliponiculture present the potential to be mechanisms of biological conservation, although, for this, adequate training and technical references are necessary. Knowledge of management practices, seasonality, and the keeping of local species are essential for this (VILLAS-BÔAS, 2018). As a safe conduct, commercial meliponaries have a large number of colonies, so it is necessary to plant melitophilous pasture that supports those populations. It is, also, necessary to take precautions to prevent the proliferation of diseases, as well as to avoid the keeping of non-endemic bee species. Another relevant aspect is that commercial meliponaries are focused on a small number of species, while hobbyist meliponists tend to have fewer colonies, but of several species, although many stingless bee species have sophisticated or non-established management practices, being rarely kept by meliponists.

\section{Interdisciplinary approaches}

The examples briefly discussed for each Domain are only small parts that make up a much larger universe. If, within each Domain, we can analyze and discuss several issues grouped or separately, the same goes for the Domains themselves, which make up the universe of meliponiculture. This myriad of aspects and factors must be understood in a similar way to a pyramid: when looking at one face, it is not possible to be aware of the others, or even the base. To understand the pyramid as a whole, it is necessary to change the point of view, in order to understand each part with the necessary attention, yet without losing sight of the whole. It is worth mentioning that each face, in turn, has smaller parts that, consecutively, are composed of their own even smaller parts. However, even though at certain times we may focus on the small parts of this fractal that forms the activity of meliponiculture, we cannot fail to pay attention to the multiple domains that compose it as a whole (Figure 5). 
Figure 5 - Multiple Domains of Meliponiculture

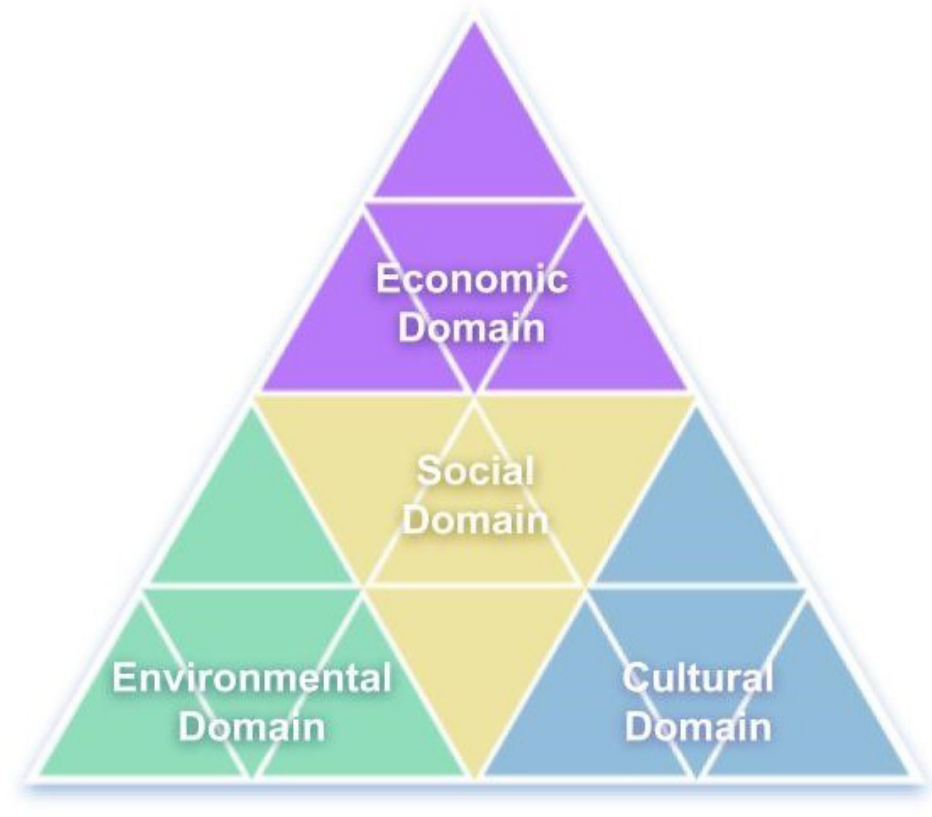

Source: Barbiéri and Francoy (2020)

In that a way, meliponiculture and its development within the context of conservation and sustainability must be treated by interdisciplinary factions, who can move between micro and macro scales, from their specific areas of knowledge to broader scales, in a way that neither contexts nor details are addressed with a lack of quality.

\section{Other examples of the application of the Sustainability pyramid model}

To exemplify the use of the analysis model proposed here, three activities with different levels of sustainability are listed below. Each of the activities can be analyzed in greater depth in other works, so these specific ones are used only for a didactic purpose, to illustrate other potential uses of the model.

1 - Agroforestry Systems are food production systems that value biodiversity and seek to draw on the natural dynamics of interactions between organisms, sometimes integrating forest management, species of food plants, and small-scale livestock. Agroforestry Systems promote sustainability in all domains (CAPORAL \& COSTABEBER, 2002). In the Environmental Domain, it promotes Biodiversity Conservation and Recovery, maintaining essential Ecosystem Services (soil quality, water bodies, soil, pollinator resources) (RIBASKI, 2008; ALMEIDA, 2010; AMADOR, 2003). In the Economic Domain, they 
generate Employment and Income, moving the regional economy, supplying various forest, agricultural, and animal products, in addition to the added value of the products due to the SAF's sustainability values (KITAMURA \& RODRIGUES, 2001; ALMEIDA, 2010). In the Cultural Domain, SAFs are very similar to Meliponiculture. They use and preserve traditional knowledge, are rich in innovation, especially concerning management techniques and species consortia, they are an excellent tool for environmental education, as a way of reconnecting between man and nature through food. They are also excellent research objects for Science, whether for the improvement and development of SAFs or a better understanding of the interactions between cultivated organisms (ALMEIDA, 2010). In the Social Domain, they promote a better quality of life, the possibility of social inclusion, incorporating men in the countryside, and valuing social interactions (CASTRO et al., 2009), and it can also be a form of leisure, as community gardens do in urban environments.

2 - Apiculture, the keeping of bees of the Apis genus, originating in Europe, Asia, and Africa. It is a well-established activity in almost the entire world, including Brazil, which contains sustainable characteristics, although to a lesser extent than meliponiculture. In the Environmental Domain, it promotes ecosystemic pollination services, although with limited possibilities when compared to the use of stingless bees (VILLAS-BÔAS, 2018). As they use exotic species for the production of honey, the contribution to biological conservation is smaller. Among beekeepers, the practice of migrating colonies according to the flowering is very recurrent, while the stingless beekeepers usually plant to provide the resources for the bees. In the Economic Domain, beekeeping is a very well-established activity, generating employment, income, bee products, applied agricultural pollination, and a market for tools and personal protection equipment. Nowadays, Apiculture generates more income than Meliponiculture, but with less potential for creating new products with high added value. In the Cultural Domain, beekeeping carries traditions consolidated for centuries, but it is still an important object of scientific research, but with smaller potential for innovation than Meliponiculture. It can also be used as an Environmental Education tool, although in this aspect, Meliponiculture has several advantages. In the Social Domain, beekeeping is a significant activity, valuing social interactions between breeders, increasing the quality of life of people in the countryside, serving as a form of social inclusion, and also as a form of leisure (GONÇALVES, 2006).

3 - Monoculture is the extensive agriculture with very low biodiversity. Although it is one of the main economic activities in Brazil, it is an unsustainable activity (TILMAN, 1999), due to the following reasons: In the Environmental Domain, due to the suppression of natural areas, low biodiversity, impoverishment of the soil, reduction of essential ecosystem services (TILMAN, 1999). On the Social Domain, due to the risks generated to workers and consumers of their products as a result of the use of pesticides, reduced contact with nature, less opportunity for social inclusion, and low quality of life for rural workers (REIS \& NETO, 2014). In the Cultural Domain, although there is significant scientific and technological development, innovation is mostly generated by the environmental unsustainability scenario, to overcome problems generated by the system itself and which are much smaller in other productive systems (ARAÚJO, 2014; 
ZIMMERMANN, 2009). In monoculture, traditional knowledge that was widespread even before the Green Revolution was lost (REIS \& NETO, 2014), and the most significant possibility of environmental education is the use of counterexamples, compared to other production methods. In the Economic Domain, monocultures are considered as an important generator of wealth, however, the model encourages the concentration of income and the precariousness of the workforce (ARAÚJO, 2014). Furthermore, although it is the source of many commodities and raw materials, the diversity of products generated by monocultures is increasingly smaller (ZIMMERMANN, 2009) than other methods.

\section{Conclusion}

The Sustainability pyramid model can be applied to the analysis of any human activity of economic interest that uses natural resources or ecosystem services. Using this model for the analysis of meliponiculture, it is possible to observe that public policies to encourage the activity should be conducted, in order to facilitate their recreational and professional practice. Besides, these policies should, also, provide technical references for the activity, in favor of developing and promoting employment and income combined with the conservation and sustainable use of biodiversity. The implementation of public policies for meliponiculture requires a plural debate with a view to sustainability at local, regional, and global scales. Such factors create an opportunity for the development of research involving stingless beekeepers as an active part of knowledge production in participatory programs that bring together scientists, companies, honey producers, stakeholders, and other sectors involved in the meliponiculture activity.

Due to the multiplicity of aspects and benefits generated by meliponiculture in the environmental, social, cultural, and economic Domains, non-interdisciplinary approaches are not sufficient to understand meliponiculture, which is an activity that promotes sustainability. Thus, approaches aimed at the elaboration of public policies for meliponiculture as an economic activity must respect the needs for the conservation of stingless bee species, and whenever possible, the social and cultural values attributed to the activity.

\section{References}

ALMEIDA, RG de, et al. Sistemas agrossilvipastoris: benefícios técnicos, econômicos, ambientais e sociais. ENCONTRO SOBRE ZOOTECNIA DE MATO GROSSO DO SUL, 2010, 7: 1-10.

Amador, D. B. (2003). Restauração de ecossistemas com sistemas agroflorestais. Restauração de ecossistemas naturais. Fundação de Estudos e Pesquisas Agrícolas e Florestais-FEPAF. São Paulo. Botucatu.

ARAÚJO, M. J; AM et al. Effect of propolis of Scaptotrigonaaff. postica on the development of the tumor of Ehrlich in mice. Revista Brasileira de Farmacognosia, v. 20, n. 4, p. 580-587, 2010. 
BRASIL. Decreto Legislativo no 2, de 3 de fevereiro de 1994. Aprova o texto da Convenção sobre Diversidade Biológica. Diário do Congresso Nacional (Seção II) Brasília, DF, 8 de fevereiro de 1994, pp. 500-510.

CASTRO, Albejamere Pereira de, et al. Os sistemas agroflorestais como alternativa de sustentabilidade em ecossistemas de várzea no Amazonas. Acta Amazonica, 2009, 39.2: 279-288.

CAPORAL, Francisco Roberto; COSTABEBER, José Antônio. Análise multidimensional da sustentabilidade. Agroecología e desenvolvimento rural sustentável, 2002, 3.3: 70-85.

COSTA, L. et al. Rescue of Stingless bee (Hymenoptera: Apidae: Meliponini) nests: an important form of mitigating impacts caused by deforestation. Sociobiology, v. 61, n. 4, p. 554-559, 2014.

DE ARAUJO, Rodrigo da Cruz. Análise sobre a monocultura de soja e o Desenvolvimento Sustentável na Amazônia com base na teoria do Desenvolvimento Endógeno. Economia e Desenvolvimento, 2014, 26.1 .

FREITAS, B. M.; PEREIRA, J. O. P. Conservationand management ofpollinators for sustainableagriculture: The international response. InA contribution to the International Workshop on solitary bees and their role in pollination held in Berberibe, Cerara, Brazil. Solitary bees: Conservation, rearing and management for pollination. Fortaleza: ImprensaUniversitária, 2004.p.42-58

FREITAS, G.S. et al. Abelhas para a melhor idade: curso de meliponíneos, alfabetização técnica para a conservação. BioscienceJournal, v. 23, 2007.

GONÇALVES, L. S. Meio século de apicultura com abelhas africanizadas no Brasil. MensagemDoce, v. 87, n. 1, p. 21-26, 2006.

HALL, D. M. et al. The city as a refuge for insect pollinators. Conservation Biology, v. 31, n. 1, p. 24-29, 2017.

HALCROFT, M. T. et al. The Australian stingless bee industry: a follow-up survey, one decade on. Journalof Apicultural Research, v. 52, n. 2, p. 1-7, 2013.

IMPERATRIZ-FONSECA, V. L.; SARAIVA, A. M.; GONÇALVES, L.S. A iniciativa brasileira de polinizadores e os avanços atuais para a compreensão do papel dos polinizadores como produtores de serviços ambientais. BioscienceJournal, v. 23, 2007.

KERR, W. K.; CARVALHO, G. A.; NASCIMENTO, V. A. Abelha Uruçu: Biologia, Manejo e Conservação. Paracatú: Acangaú, 1996. 144 p.

KERR, Warwick Estevam et al. Aspectos pouco mencionados da biodiversidade amazônica. Parcerias Estratégicas, v. 6, n. 12, p. 20-41, 2010.

KITAMURA, Paulo Choji; RODRIGUES, Geraldo Stachetti. Valoração de serviços ambientais em sistemas agroflorestais: métodos, problemas e perspectivas. In: III Congresso Brasileiro de Sistemas Agroflorestais. 2001. p. 55. 
LOPES, Marcio; FERREIRA, João Batista; DOS SANTOS, Gilberto. Abelhas sem-ferrão. APA Agriculturas, v. 2 - n $4,2005$.

MAIA-FILHO, E. M. et al. Efeito antimicrobiano in vitro de diferentes medicações endodônticas e própolis sobre Enterococcusfaecalis. RGO, v. 56, n. 1, p. 21-25, 2008.

MBEE MEL DE TERROIR. Disponível em: < http://mbee.com.br/index.html>. Acesso em: 03 de fev. 2019.

MESQUITA, T. M. S. Diversidade de abelhas solitárias (Hymenoptera, Apoidea) que nidificam em ninhos-armadilha em áreas de Cerrado, MG. 2009. 50 f. Dissertação (Mestrado em Entomologia) - Universidade Federal de Uberlândia, Uberlândia, 2009.

OLIVEIRA, F. F. et al .Guia Ilustrado das Abelhas Sem-Ferrão das Reservas Amanã e Mamirauá, Amazonas, Brasil (Hymenoptera, Apidae, Meliponini). Tefé: Instituto de Desenvolvimento Sustentável Mamirauá IDSM/OS/MCTI, 2013.

PALAZUELOS BALLIVIAN, J. M. P.; UTERMOEHL B. ; SOARES, V. M. . Abelhas nativas sem ferrão. 2. ed. São Leopoldo: OIKOS, 2008. v. 1. 128p.

PERUCHI, Rosane M. G.; GONÇALVES, L. S.; .SEM ABELHA SEM ALIMENTO: Caderno de Atividades para Educação Ambiental. 1a.. ed. Rio de Janeiro: FUNBIO, 2015. v. 1. 56p.

POSEY, D. A.; CAMARGO, J.M.F. Additional notes on the classification and knowledge of stingless bees (Meliponinae, Apidae, Hymenoptera) by Kayapóindians of Gorotire, Pará, Brazil. Annals of Carnegie Museum, v. 54, n. 8, p. 247-274, 1985.

POTTS, Simon G. et al. The assessment report of the Intergovernmental Science-Policy Platform on Biodiversity and Ecosystem Services on pollinators, pollination and food production. 2016.

Reis, L. C. S., \& Neto, J. D. C. G. (2014). Produção de alimentos: agricultura familiar x cultura de exportação no Brasil, sob a perspectiva da sustentabilidade. Revista Brasileira de Políticas Públicas, 4(1).

RIBASKI, Jorge. Sistemas agroflorestais: benefícios socioeconômicos e ambientais. In: Embrapa Florestas-Artigo em anais de congresso (ALICE). In: SIMPÓSIO SOBRE REFLORESTAMENTO NA REGIÃO SUDOESTE DA BAHIA, 2., 2005, Vitória da Conquista. Memórias. Colombo: Embrapa Florestas, 2008. p. 89-101.

RODRIGUES, C. G. et al. Leaf fertilizers affect survival and behavior of the Neotropical stingless bee Friesellaschrottkyi (Meliponini: Apidae: Hymenoptera). Journal of economic entomology, v. 109, n. 3, p. 1001-1008, 2016.

ROSA, A. S., et al. Consumption of the neonicotinoid thiamethoxam during the larval stage affects the survival and development of the stingless bee, Scaptotrigonaaff. depilis. Apidologie, v. 47, n. 6, p. 729-738, 2016. 
ROSA, A.S, et al. The stingless bee species, Scaptotrigonaaff. depilis, as a potential indicator of environmental pesticide contamination. Environmental toxicology and chemistry, v. 34, n. 8, p. 1851-1853, 2015.

SILVEIRA, F. A. et al. Taxonomic constraints for the conservation and sustainable use of wild pollinators-the Brazilian wild bees. Pollinating bees -the conservation link between agriculture and nature. Brasilia, Ministry of Environment, p. 41-50, 2002.

SOS ABELHAS SEM FERRÃO. Institucional. Disponível em: < http://sosabelhassemferrao. com.br/site/>. Acessoem: 04 de fev 2019.

TILMAN, David. Global environmental impacts of agricultural expansion: the need for sustainable and efficient practices. Proceedings of the National Academy of Sciences, 1999, 96.11: 5995-6000.

VENTURIERI, G.C. et al. Caracterização, colheita, conservação e embalagem de méis de abelhas indígenas sem ferrão. Belém: Embrapa Amazônia Oriental, 2007

VENTURIERI, G. C. et al. Caracterização e avaliação de abelhas indígenas e de plantas melíferas utilizadas para a produção de mel, entre os pequenos agricultores da Amazônia Oriental. Relatório de Pesquisa. Belém: EMBRAPA, 2003.

VILLAS-BÔAS, J. K. As abelhas nativas e a experiência da meliponicultura.In VILLAS-BÔAS, A. et al.(Org) XINGU : Histórias dos produtos da floresta. São Paulo. Instituto Socioambiental, 2017.p 93-120.

VILLAS-BÔAS, J. K. Manual Tecnológico de Aproveitamento Integral dos Produtos das Abelhas Nativas Sem Ferrão. Brasília - DF. Instituto Sociedade, População e Natureza (ISPN). 2a edição. Brasil, 2018.

ZIMMERMANN, Cirlene Luiza. Monocultura e transgenia: impactos ambientais e insegurança alimentar. Veredas do Direito: Direito Ambiental e Desenvolvimento Sustentável, 2011, 6.12. 


\section{Celso Barbiéri}

ఐbarbieri@usp.br

ORCiD: https://orcid.org/0000-0002-7790-1371
Submitted on: 16/03/2019

Accepted on: 20/01/2020

2020;23:e00202

\section{Tiago Mauricio Francoy}

๑tfrancoy@usp.br

ORCiD: https://orcid.org/0000-0002-2413-966X

How to cite: BARBIÉRI, C.; FRANCOY, T. M. Theoretical model for interdisciplinary analysis of human activities: Meliponiculture as an activity that promotes sustainability. Ambiente \& Sociedade. São Paulo, v. 23, p. 1-19, 2020. 


\title{
Modelo teórico para análise interdisciplinar de atividades humanas: A meliponicultura como atividade promotora da sustentabilidade
}

\author{
Celso Barbiéri \\ Tiago Mauricio Francoy
}

São Paulo. Vol. 23, 2020

Artigo Original
Resumo: A meliponicultura, que é a criação racional de abelhas sem ferrão, é praticada há séculos por populações tradicionais e vem ganhando adeptos nos últimos anos. Além de ser uma alternativa para a conservação desses polinizadores, trata-se de uma atividade promotora de sustentabilidade. Do ponto de vista teórico, abordagens disciplinares se demonstram insuficientes para a compreensão da meliponicultura, devido à multiplicidade de Domínios e aspectos que a compõem. Assim, propomos um modelo teórico para analisar a meliponicultura de forma interdisciplinar, tratando dos Domínios ambiental, cultural, social e econômico. Tal atividade deve ser incentivada por meio de políticas públicas participativas e interdisciplinares, integrando os diversos atores envolvidos, como meliponicultores, cientistas, governos, empresas e organizações não governamentais. Abordagens de políticas públicas para a meliponicultura enquanto atividade econômica devem respeitar as necessidades de conservação das espécies de abelhas sem ferrão e, sempre que possível, os valores sociais e culturais atribuídos à atividade.

Palavras-chave: Abelhas sem Ferrão, Interdisciplinaridade, Biologia da conservação

Como citar: BARBIÉRI, C.; FRANCOY, T. M. Modelo teórico para análise interdisciplinar de atividades humanas: A meliponicultura como atividade promotora da sustentabilidade. Ambiente $\mathbb{\&}$ Sociedade. São Paulo, v. 23, p. 1-20, 2020. 


\title{
Modelo teórico para el análisis interdisciplinario de las actividades humanas: La meliponicultura como actividad promotora de la sostenibilidad
}

\author{
Celso Barbiéri \\ Tiago Mauricio Francoy
}

São Paulo. Vol. 23, 2020

Artículo original
Resumen: La meliponicultura, entendida como la crianza de abejassinaguijón, es practicada desde hacesiglos por poblacionestradicionales y vieneganando adeptos enlos últimos años. Además de ser una alternativa para conservación de esos polinizadores, es uma actividad promotora de sostenibilidad. Abordajes disciplinares se han mostrado insuficientes para lacomprensión de la meliponicultura, dada la multiplicidad de dominios y aspectos que lacomponen. De esa forma, proponemosun modelo teórico para analizarlameliponiultura de forma interdisciplinar, incorporando losdominios ambiental, cultural, social y económico. Dichaactividaddebe ser incentivada por medio de políticas públicas participativas e interdisciplinarias, integrando los diversos actores involucrados, tales como meliponicultores, científicos, gobiernos, empresas y organizaciones no gubernamentales. Abordajes de políticas públicas para la meliponicultura como actividad económica debenrespetarlasnecesidades de conservación de lasespecies de abejassinaguijón y los valores sociales y culturalesatribuidos a esaactividad.

Palabras-clave: Abejas sinaguijón, interdisciplinariedad, Biología de la conservación.

Como citar: BARBIÉRI, C.; FRANCOY, T. M. Modelo teórico para el análisis interdisciplinario de las actividades humanas: La meliponicultura como actividad promotora de la sostenibilidad. Ambiente $\boldsymbol{\&}$ Sociedade. São Paulo, v. 23, p. 1-20, 2020. 